PERM JOURNAL OF PETROLEUM AND MINING ENGINEERING

ВЕСТНИК ПНИПУ. ГЕОЛОГИЯ. НЕФТЕГАЗОВОЕ И ГОРНОЕ ДЕ

ISSN 2224-9923

Volume/ Tом 16 №2, 2017

http://vestnik.pstu.ru/geo/

УДК 622.276.5.001.5

Article / Статья

(C) PNRPU / ПНИПУ, 2017

\title{
INCREASE IN EFFICIENCY OF METHODS OF BOTTOMHOLE FORMATION ZONE TREATMENT IN ACTIVE WELLS BY INFORMATION TECHNIQUE
}

\section{Anatolii I. Dziubenko, Andrei N. Nikonov', Mikhail E. Merson ${ }^{2}$}

INNO TECHNOLOGY LLC (39 Gagarina blvd, Perm, 614070, Russian Federation)

${ }^{1}$ Universal-Service LLC (54 Petropavlovskaia st., Perm, 614000, Russian Federation)

${ }^{2}$ Geology Company Isotop (20 Gaiarok st., Hadera, 7075001, State of Israel)

\section{ИНФОРМАЦИОННЫЙ СПОСОБ ПОВЫШЕНИЯ ЭФФЕКТИВНОСТИ МЕТОДОВ ВОЗДЕЙСТВИЯ НА ПРИЗАБОЙНУЮ ЗОНУ ПЛАСТА В ДЕЙСТВУЮЩИХ СКВАЖИНАХ}

\author{
А.И. Дзюбенко, А.Н. Никонов ${ }^{1}$, М.Э. Мерсон ${ }^{2}$ \\ ООО «Инно-Технолоджи» (614070, Россия, г. Пермь, бульвар Гагарина, 39) \\ ${ }^{1} \mathrm{OOO}$ «Универсал-Сервис» (614000, Россия, г. Пермь, ул. Петропавловская, 54) \\ ${ }^{2}$ Геологическая компания Isotop (7075001, Израиль, г. Гедера, ул. Гаярок, 20)
}

Received / Получена: 17.03.2017. Accepted / Принята: 15.05.2017. Published / Опубликована: 30.06.2017

Key words:

well, formation, bottomhole formation zone, skin-effect, parameters, productivity, reduced radius, drainage system, hydrodynamic resistance, efficiency, specific surface, formation drainage filter.

Ключевые слова скважина, пласт, призабойная зона, скин-фактор, параметры, продуктивность, приведенный радиус, дренажная система гидродинамическое сопротивление, эффективность, удельная поверхность, пластово-дренажный фильтр.

\begin{abstract}
The paper review efficiency of geological and technological methods (GTM) of bottomhole formation zone (BHFZ) treatment that increase productivity of production wells. Today, according to directional documents, value of skin-effect $(S)$ which is determined by calculations based on well-test is the main information to screen a GTM. The greater positive value of $S$-effect at the same production rates, the earlier it is planned to carry out a GTM on a well. Wells with negative value of $S$ take the last place. The larger value, the less probability of GTM application. There is no relation between S value and parameters of a particular GTM technology. That is caused by physical nature of this dimensionless coefficient. According to directional documents, $S$ gives a generalized virtual assessment of BHFZ state through the principles of good-bad and more-less. Thus, BHFZ characteristics needed to select parameters for a particular technology of GTM application in each well remain unknown. An analysis of real physical objects that constitute structural basis of BHFZ whose properties determine value of $S$ is performed. A historical review of development of this parameter since 1949 is given. It is established that generalized unified characteristic of BHFZ basically reflects its two properties, that are diriment in structural feature that are specific surface of a well drainage system and hydrodynamic resistance of its formation fluid. A technique for determination numerical values of these parameters is proposed. There are examples of application of proposed BHFZ characteristics for analysis of reasons of change in productivity of a production well of Perm region during 4 years of operation and reasons for change in productivity of five more wells after the GTM application are given in conclusion.
\end{abstract}

Рассмотрена эффективность геолого-технологических методов (ГТМ) воздействия на призабойную зону продуктивных пластов (ПЗП) для увеличения производительности дренирующих их скважин. В настоящее время основной информацией для выбора технологии ГТМ, соответствующей состоянию конкретной ПЗП, является, согласно руководящим документам, величина скин-фактора $(S)$, определяемая расчетным путем по результатам гидродинамических исследований скважин. Чем больше положительная величина этого коэффициента при одинаковых дебитах, тем раньше планируется проведение ГТМ в скважине. На последнем месте остаются скважины с отрицательным значением $S$. Чем больше его величина, тем меньше вероятность проведения ГТМ. Никакого отношения к выбору параметров конкретной технологии ГТМ величина $S$ не имеет. Причиной тому служит физическая сущность данного безразмерного коэффициента. Согласно руководящим документам, он дает некую обобщенную виртуальную оценку состояния ПЗП скважины по принципам хорошее - плохое и более менее. Таким образом, характеристики ПЗП, необходимые для выбора параметров конкретной технологии проведения ГТМ в каждой скважине, остаются неизвестными.

В работе выполнен анализ реальных физических объектов, составляющих конструктивную основу ПЗП, свойства которых определяют величину $S$. Приведен исторический обзор развития данного параметра начиная с 1949 г. Установлено, что обобщенная единая характеристика ПЗП в основном отображает два ее свойства, отличающиеся по конструктивному признаку, - это удельная поверхность дренажной системы скважины и гидродинамическое сопротивление ее пластового фильтра. Предложена методика определения численных значений этих параметров. В заключение приведены примеры практического использования предложенных характеристик ПЗП для анализа причин изменения продуктивности одной из добывающих скважин Пермского края в процессе ее четырехлетней эксплуатации и причин изменения продуктивности еще пяти скважин после ГТМ.

Anatolii I. Dziubenko - Mining Engineer, Lead Geologist-interpretator (mob. tel.: +007912 58680 67, e-mail: idd3011@yandex.ru). The contact person for correspondence. Andrei N. Nikonov - Engineer-geophysicist, Director (mob. tel.: +007 91947820 08, e-mail: Anikonov@usvc.pnsh.ru). Mikhail E. Merson - Consultant (tel.: +007912 58680 67, e-mail: idd3011@yandex.ru).

Дзюбенко Анатолий Иванович - горный инженер, старший геолог-интерпретатор (моб. тел.: +007 91258680 67, e-mail: idd3011@уandex.ru). Контактное лицо для переписки.

Никонов Андрей Николаевич - инженер-геофизик, директор (моб. тел.: +007 91947820 08, e-mail: Anikonov@usvc.pnsh.ru)

Мерсон Михаил Эдуардович - консультант (тел. +007 91258680 67, e-mail: idd3011@yandex.ru). 


\section{Introduction}

Increase in time of operation of production wells that pump a productive reservoir in oil fields causes the fact that state of a bottomhole formation zone (BHFZ) that plays a role of a filter in a drainage system of wells is changed. Multidirectional movement of various fluids in that zone during operation is accompanied by either blockage or cleaning of its free space, which significantly affects well productivity. Therefore, assessment of a real state of BHFZ is one of the most important tasks that determines a direction of work to improve efficiency of well operation including a technology for BHFZ stimulation in particular conditions that has to be chosen.

Today, a value of skin factor $S$ that is the main parameter for assessing the state of BHFZ is used everywhere [1]. For the first time that was used in oil production in 1949 by an American scientist Van Everdingen. He called it a dimensionless factor reflecting properties of a film that covers penetrating (infiltrating) surface of a well and hinder free movement of fluids between a well and formation. Dimensions of that parameter and its physical nature were determined by the following expression:

$$
S=\left(k-k^{*}\right) / k^{*} x \ln \left(r_{a} / r_{w}\right)
$$

where $k, k^{*}$ are permeabilities of the main formation; $r_{a}, r_{w}$ are radii of BHFZ and well respectively.

That was not consider to obtain large values of $\mathrm{S}<<-1$.

Later a practical method for determination of a value from pressure build up curve (PBC) is taken in a stopped well during field well test [2].

$$
S=(b / i)-\ln \left(2,25 \ddot{z} / r_{w}^{2}\right),
$$

where $b, i$ and $x$ are the parameters calculated from the $\mathrm{PBC}$, reconstructed in semilogarithmic coordinates.

That a dimensionless parameter was widely used in our and foreign practice of oil production as a multiuse one for assessing the state of BHFZ. However, during accumulation of information on well survey it was determined that in a sufficiently large number of cases the parameter value becomes negative and large. Essentially, this means that at $S=0$ a virtual cover is washed off from the well walls. If the value continues to decrease $S$ appears again as a virtual physical nonsense, real physical essence of which will be interpreted by every speciallist in different way until their own interpretation is included a guideline document.

\section{Current state of the issue of real BHFZ parameters estimation}

In order to eliminate uncertainties in evluation of BHFZ state another dimensionless parameter such as damage factor is used in American practice since $1953(1-P R)$. That was developed by Tomas [12] as a coefficient of zonal damage, where $P R=k^{*} / k$ is a ratio equal to $Q^{*} / Q$ if other parameters that determine real and calculated rates are equal. Positive value of a factor from 0 to +1 indicates a damage (deterioration) of BHFZ. Negative value of a factor from 0 to $-\infty$ on contrary indicates its improvement. Numerical value of a parameter, other than zero, determines degree of deviation of flow penetration property of BHFZ from the natural state of the main reservoir. The disadvantage of this parameter is asymmetry of its boundary estimates. Therefore, although possible use of $1 / P R$ instead of 1 could provide the necessary property, only a positive part of them has received practical application.

Since 1953 a more meaningful parameter such as reduced well radius is used in domestic practice with the same purpose. That is virtual radius of some perfect well operating with production rate of a real well at interval of a productive formation [13-20]. That radius $r_{\text {red }}=r_{\mathrm{w}} \cdot e^{-c}$ is calculated using $C=C_{1}+C_{2}$, obtained from Shchurov's charts [20], that represent $C_{1}$ and $C_{2}$ as functions from a method of casing perforation and degree of productive formation penetration. Since 1985 official documents $[22,23]$ require to calculate $r_{\text {red }}$ through $b / i$ and $x$, that are parameters determined from semi logarithmic anamorphosis of $\mathrm{PBC}$, and use Skin-factor $S=\ln \left(r_{\mathrm{w}} / r_{\text {red }}\right)$ (instead of Shchurov's coefficients) that is numerically not equal to calculated by formula (2) but reliable in terms of virtual physical nature. These changes were confirmed by later [24] domestic guidelines. 
Unfortunately, even this version of a parameter that characterise a state of BHFZ showed its inefficiency shortly. Indeed, having its design values varying in the range $0-0.01 \mathrm{~cm}$, real throughput of a pipeline or any well, is reset to zero a reservoir fluid. In this case, reduced radius $r_{\text {red }}$ together with a virtual well becomes meaningless. In the opposite case, when calculated reduced radius of tested wells approaches to size of radius of their feeding zone (and exceeds it sometimes) meaningless objects are obtained again. And again we go beyond the well-known. Neither virtual nor real physical objects can be meaningless (nonsense).

Reduced radius and a virtual well become meaningless objects. In the opposite case, when a calculated reduced radius of tested wells approaches to size of radius of their feeding zone (and exceeds it sometimes) then again from virtual ones we get meaningless objects. We go beyond the well-known again. Neither virtual nor real physical objects can be meaningless (nonsense).

Despite this fact, incredible values of skin factor and reduced radius of production wells continue to appear in report technical documentation and data banks for control of field development, which puzzle engineering and technical staff of the oil fields.

Recently, there are in some publications $[25,26]$ new computational operations are proposed as methods of overcoming a still urgent challenges. Those operations increase accuracy of determination of above parameters that evaluate BHFZ state. However, since the virtual essence of parameters in such works remains unchanged efficiency of well operation cannot be increased this way. In this case dynamics of comparative estimates of real physical objects has a practical value.

\section{Upgrade of the method for determination of BHFZ state}

An araised issue can be solved at more careful analysis of modern theoretical bases of development of oil fields. For example, there are two main factors recognized by oil field personnel among objective factors characterizing well design and complicating movement of fluid between a productive formation and wells. Those factors are surface area of a drainage system (i.e. well radius as the best case) and value of hydrodynamic resistance of BHFZ as a formation filter. [27]. At the same time, modern guidelines recommend to use only generalized characteristics of the object of interest. Therefore, for more correct and clear understanding of structure of BHFZ it is advisable to use quite correct parameters, physical essence of which corresponds to real design of wells and properties of a productive reservoir. Obviously, such parameters should include a specific surface of a drainage system (SSDS) of a well $r_{\text {red }}^{* *}$ and $S$ which represents dimensionless hydrodynamic resistance of its formation-drainage filter (FDF). Among the parameters presented in formula (1), $S$ includes a number of parameters characterizing constantly changing properties of a reservoir continuum, including velocity of the fluids, their composition, properties, pressure in BHFZ etc. Their magnitude determine constantly changing size and throughput properties of a filter. In case of positive values of $S$ parameter, resistance of BHFZ increases in comparison with a reservoir value, which is equal to $\ln \left(R / r_{\text {red }}^{* *}\right)$, while for negative values it decreases on contrary.

The method for determination the parameter does not require special explanation, since it is specified by relevant guidance documents [11]. The most probable filter size is calculated in accordance with [28-30].

An ideal understanding of the physical essence and magnitude of the first parameter can be obtained by considering results of the initial full opening of a productive formation. In this case, part of the real wellbore located in a productive formation is its drain. A part of a lateral surface of the drain i.e. borehole area surface that belongs to length of the drain, is the required quantity. Obtained SSDS (cm), corresponds to a reduced well radius $r_{\text {red }}^{* *}$, which is relative reduced in 6.28 times by quantitative characteristic of this parameter. The physical essence of the parameter will not change in front of other methods of opening a productive formation for its drainage as well. Its magnitude varies only. 
Determination of SSDS can be performed through generally known Dupuis formula if well productivity index is a function instead of well production rate.

$$
K=2 \pi \dot{\varepsilon} / \ln \left(R / r_{r e d}^{*}\right) .
$$

All the constituent parameters of this formula except redused well radius $r_{\text {red }}^{*}$ are determined expirementally. As a result of well test using constant rate method $K$ is determined before a well was stopped for PBC; $\dot{\varepsilon}$ (formation conductivity) is determined by $\mathrm{PBC}, R$ parameter is determined as a half of length between wells in a network, i.e. well influende area in accordance with head documents. Equation is solved in respect to an unknown parameter. Then analogous parameter of $r_{\text {red }}$ was determined earlier by PBC. In accordance with the requirements of RD 153-39.0-109-01 [12], corresponding parameters of $S^{*}$ and $S$ are calculated for obtained reduced radii. Such calculations were performed based on results of study of 20 wells at 11 fields of Perm region. Fig. $1 a$ shows the graph of the relationship between the results obtained.

It is seen from the chart that $S^{*}$ has systematically higher values in all the range of values. That can be caused by the effect on calculation of different reservoir coditions that is common for different methods of well test. The parameter $S^{*}$ is determined based on results of test of working wells, i.e. in conditions of speed fluid movement in BHFZ. The parameter $S$ is determined in all other wells, i.e. with no analogue fluid movement in BHFZ. Here, in accordance with Shchurov's theory it is possible to write an equation $S^{*}=S+C$, where a parameter $C$ reflects a value of additional hydrodynamic resistance that appear in BHFZ when flud moves. It is clear that those resistances are located in an BHFZ, which is as close as possible to drane wall where the maximum speeds are concentrated. Hydrodynamic resistances inside the drain are negligible. Moreover, it has to be noted that BHFZ in terms of time is not included in information field of PBC. Now, using obtained values of $C$ in accordance with head documents it is possible to determine $r_{\text {red }}^{* *}$ (true reduced well radius) that represent a value proportional to SSDS. If $C=0$ then $r_{\text {red }}^{* *}=r_{\mathrm{w}}$.
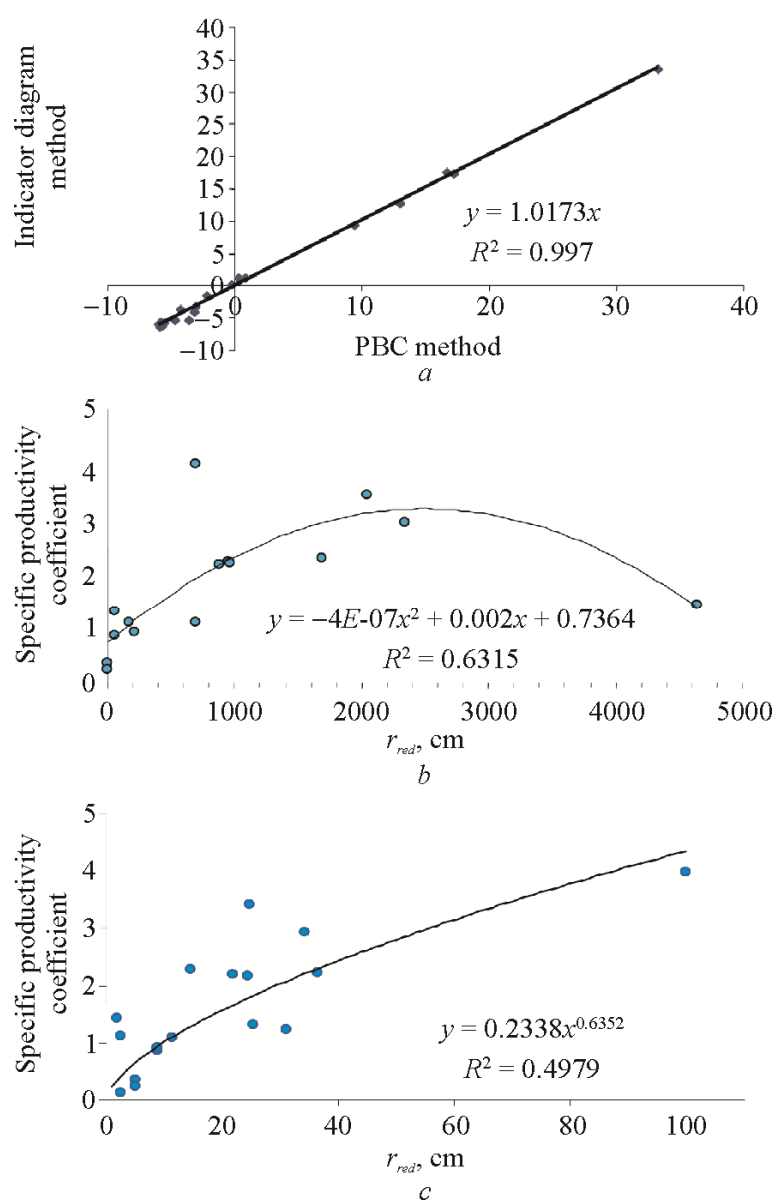

Fig. 1. Dependencies between: $a-S$ values, determined by different methods of well test; $b$ - productivity and reduced wellbore radius for $\mathrm{PBC}$; $c$ - productivity and true reduced radius of wells

To assess a degree of influence of two reduced radii on productivity of wells we use its dimensionless analogue as a function. Specific coefficient of productivity is a part of the coefficient calculated by a method of constant rates per unit of hydraulic conductivity of a formation, determined by PBC. Unfiltered results of calculations performed for 15 wells, 7 deposits and 13 fields of Perm region are shown in Fig. 1, b, c.

The graphs show existence of logical relationships between the parameters studied, but the nature of these relationships is not the same. So, with increase in values of parameters at initial sections of the graphs, a similar dynamics of their productivity is observed, which corresponds to requirements of theoretical basis (3). This trend is maintained in the second case with their further increase in the second version (see Fig. 1, c), while the first case is reversed (see Fig. 1, b) which 
contradicts (3). Another negative characteristic of this case is a zero value of the parameters. Well productivity in this case in accordance with the formula (3) should not be equal to zero as well, but this is not the case shown in Fig. 1, $b$. The third negative sign for the first sample is observed on $X$ axis of the graphs. With a real well radius of about $10 \mathrm{~cm}$, these values, shown in Fig. $1, b$, are unlikely to appear. More real are the figures shown in Fig. 1.

Presented analysis allows to propose reduced well radius, called true (actual), to use for practical purposes. It corresponds to SSDS and can deviate within a reasonable range from the actual radius of wells, reflecting either blockage of its drainage systems or formation of new penetrating (infiltrating) surfaces. There is no changes in terms of internal dimensionless hydrodynamic resistance of a well, except for a virtual cover film which is not considered anymore. $S$ value is simply added to analogous resistance of a well drainage system.

To verify the efficiency of proposed specifications it was necessary to calculate well flow rates using the Dupuyi's formula with substitution of the above parameters into it and compare with real rates. Herewith, in the first case when performing calculations in a denominator (3), we use a parameter $\ln R / r_{\text {red }}$ and $\left(\ln R / r_{\text {red }}^{* *}+S\right)$ in the second case. Fig. 2 shows results of comparison of the rates calculated according to the first case for 15 studied wells.

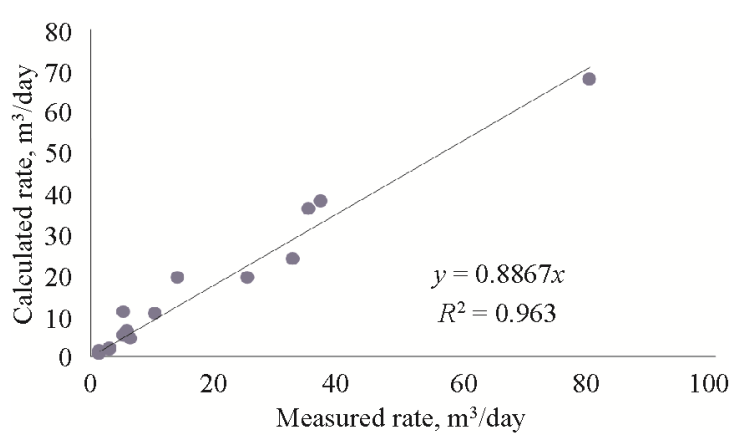

Fig. 2. The ratio of well flow rates measured and calculated

Rates of the same wells calculated according to the second case of the Dupui's formula are not represented graphically, because they are identical to those obtained as a result of measurements. It is clear that this case of calculations has real advantages.

\section{An example of practical use of allocated characteristics of BHFZ}

In order to use recommended parameters of BHFZ it is offered to evaluate how they affect well productivity. In the Fig. 3 below such an evaluation is made on example of the six-time test of well 182 of Ariazhskoe field, which gives almost no water in its production.

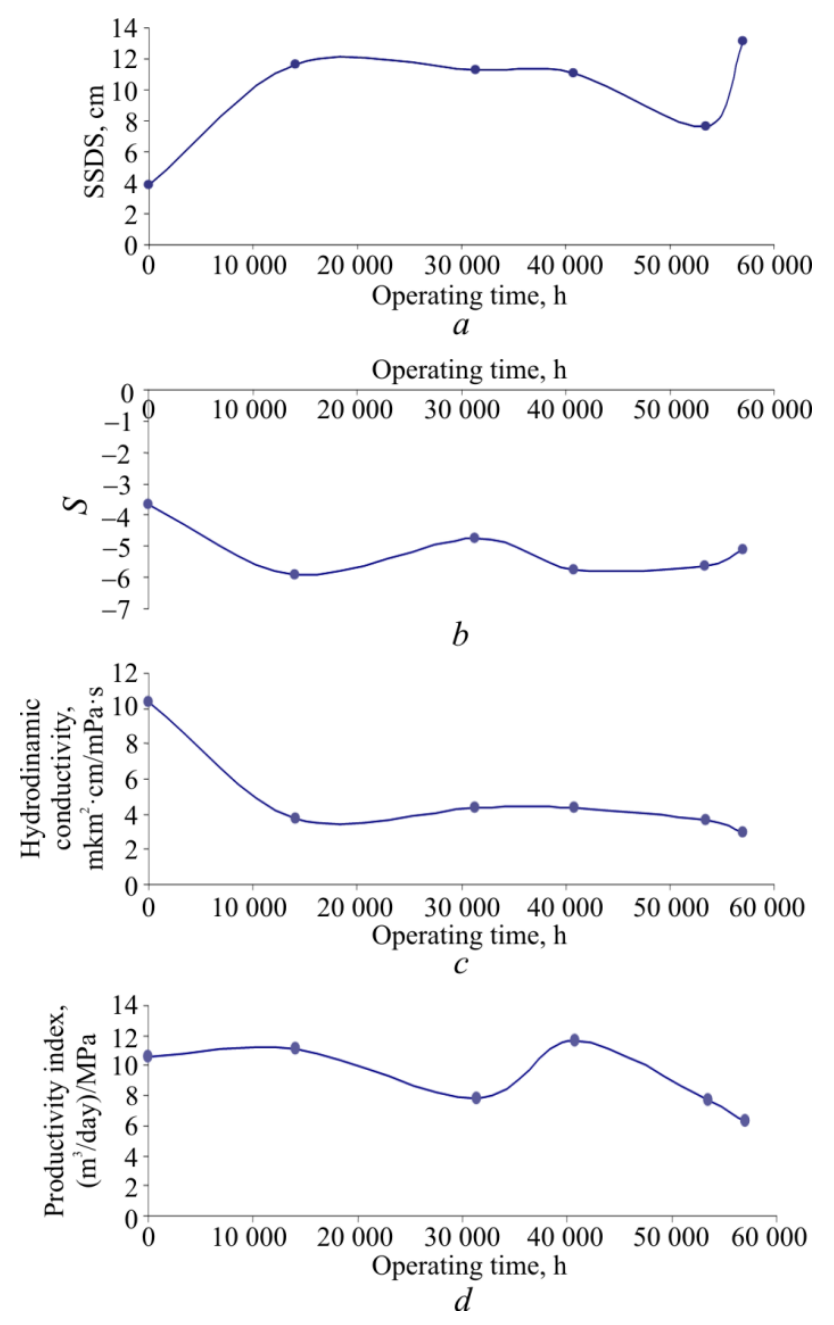

Fig. 3. Dynamics: $a-\operatorname{SSDS} ; b-S$;

$c$-hydraulic conductivity; $d$ - well productivity

Fig. 3, $d$ shows that there is $5 \%$ increase in well productivity index at the first period of operation. However, hydraulic conductivity of a reservoir (see Fig. 3, c), which directly affects a value of this coefficient, at the same time 
decreases by $65 \%$. At the same time, a degree of cleaning of FDF is increased by $60 \%$ (see Fig. 3, $b$ ) and well SSDS is increased in 3 times (see Fig. $3, a$ ). As we can see, positive dynamics of the last two factors neutralized negative impact of decreased fluid-conducting properties of the main productive reservoir on well productivity. After analysis of the penultimate period of operation in the same way it is easy to see that at this stage decrease in well productivity was mainly caused by a decrease in an area of its drainage system. In other words there was a blockage of BHFZ walls of virtual well bore.

Another example is shown in Fig. 4, where you can see results of stimulation on five randomly selected wells. First two wells drilled clastic reservoir, others drilled carbonate one. Wells are located on four fields of Perm region.

According to the charts built from results of well test before and after stimulation the most successful is a technology used in the second well (injector) and the fourth (producer). Rather intensive stimulation of remote part of reservoir caused contamination of a reservoir filter in the first well. A negative result in the third

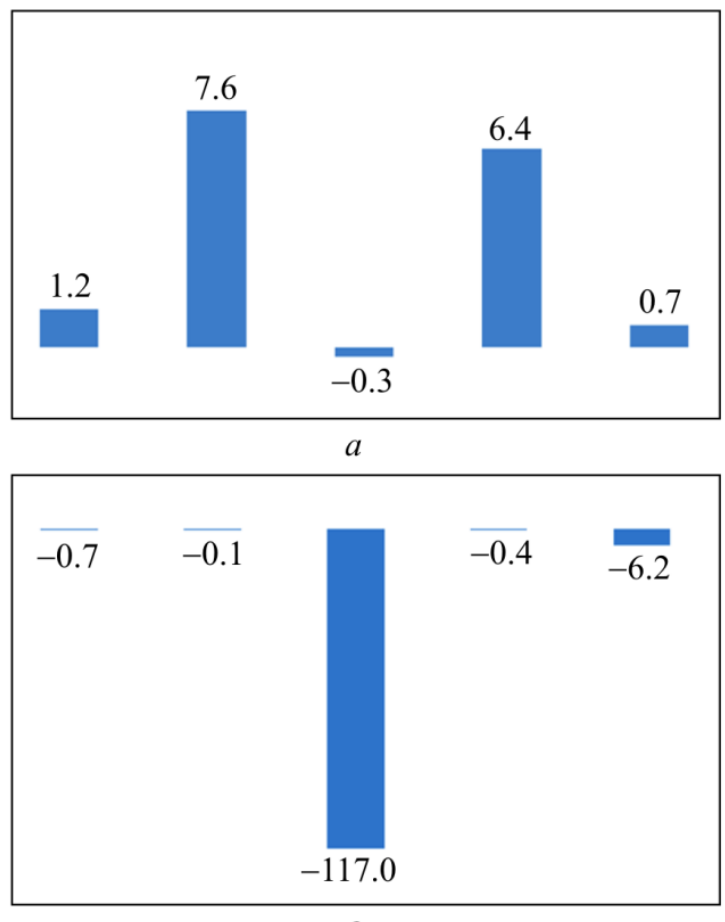

$c$ production well was obtained mainly due to blockage of a surface of a well drainage system, despite the slight purification of its filter. There is a small positive effect obtained in the fifth well (producer) mainly due to cleaning of a formation drainage filter; a remote reservoir zone was contaminated largely; well drainage system is partially blocked. In case of no data on parameters of stimulation technology it is impossible to give recommendations regarding violations that reduced efficiency of stimulation.

In order to have detailed understanding about changes occurred after stimulation in the zone of a formation drainage filter of wells a graphoanalytical method to study formula (1) with substitution of previously found values into it. The most probable changes in extreme numerical values of physical parameters that determine $S$ value are shown in Fig. 5.

The figure shows that in our case of negative initial values of the parameter $S$, the change in external dimensions of the FDF after stimulation affects the change in its hydrodynamic resistance more significantly than the dynamics of throughput.

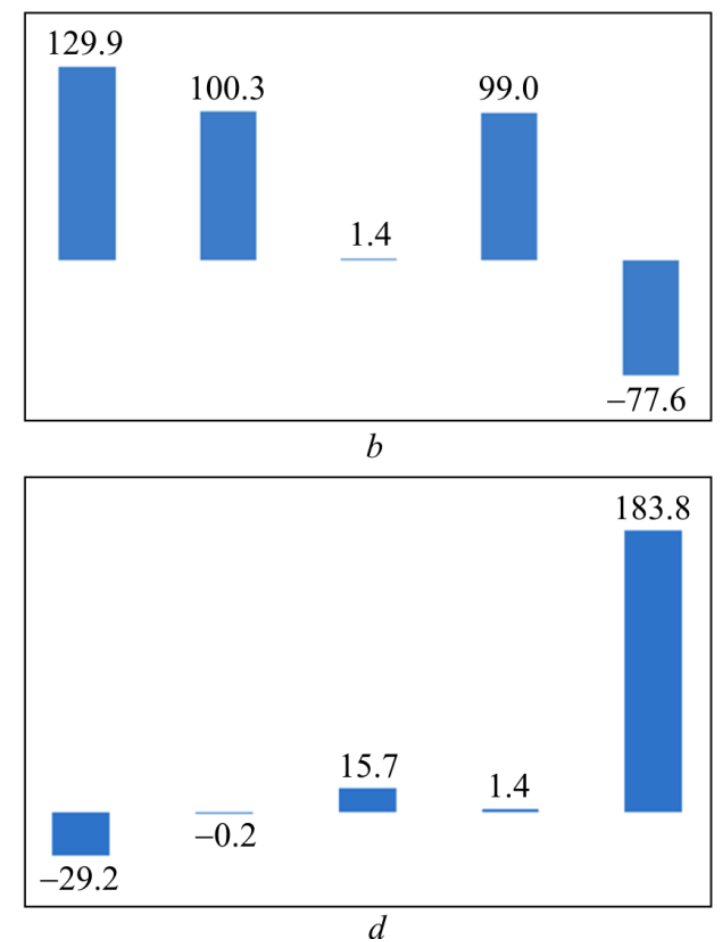

Fig. 4. Influence of properties of RFZ and BHFZ on results of stimulation in five wells: $a$ - relative increase in well productivity index; $b$ - effect of formation hydraulic conductivity, $\%$; $c$-impact of well SSDS, $\% ; d$ - effect of hydrodynamic resistance FDF, $\%$ 

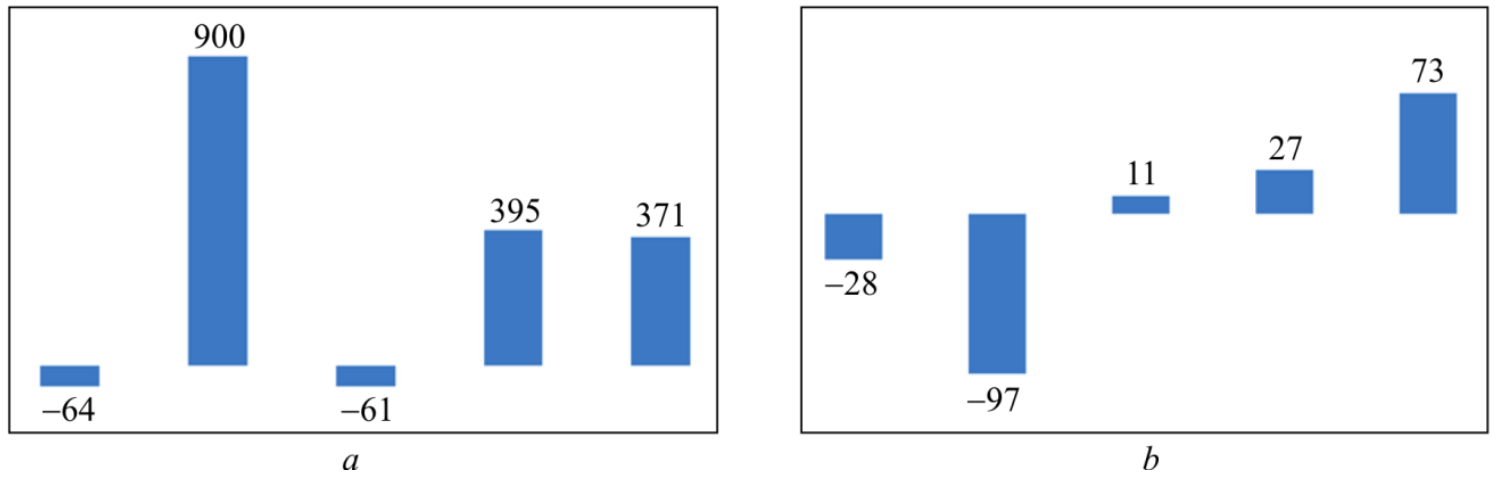

Fig. 5. Relative change in characteristics that determine the value of $S$ after well stimulation: $a$ - hydraulic conductivity of FDF, $\% ; b-$ size of FDF, $\%$

Thus, having received a package of proposed information on the state of BHFZ, including well SSDS (specific surface of drainage system) and parameter S (hydrodynamic resistance of its FDF), field technology service can easily choose most optimal stimulation regime with calculated expected increase in well productivity. Chosen technology determines the type of agent, its amount, location of implementation in a well, pumping regimes, maintaining and removal and will be passed either to cleaning or artificial increase of well drainage surface system or decrease of hydrodynamic resistance of its formation drainage filter or combined influence. In any case, second well tests will show which real, rather than virtual, well parameters have been changed and by what value.

\section{Conclusion}

1. It is established that a single generalized characteristic of BHFZ state in each well makes it difficult to select parameters of a technology for stimulation of BHFZ in order to increase efficiency of well operation.

2. The technique for differentiating evaluation of BHFZ state is suggested. That includes determination of a specific surface area of well drainage system and values of hydrodynamic resistance of a formation drainage filter.

3. Based on the example of results of systematic well tests possibilities of using the proposed characteristics of BHFZ are shown to identify reasons of change in productivity of a well that is operating for a long time.

4. Based on results of well tests conducted before and after stimulation, possibilities of using above mentioned parameters to determine reasons for decrease in efficiency of implemented technologies are shown.

5. The main directions of differentiated approach to planning of stimulation technology for specific bottomhole conditions for each well are indicated.

\section{References}

1. Van Everdingen A.F., Hurst W. The application of the laplace transformation to flow problems in reservoirs. Journal of Petroleum Technology, 1949, vol.1, no.12, pp.305-323. DOI: 10.2118/949305-G

2. Joers C.J., Smith R.V. Determination of effective formation permeabilities and operation efficiencies. The Petroleum Engineer, 1954, no.11, pp. 15-22.

3. Miller C.C., Dyis A.B., Hutchinson C.A. The estimation of permeability and reservoir pressure from bottom - hole pressure build - up characteristics. Journal of Petroleum Technology, 1950, vol. 2, no.4, pp.91-104. DOI:10.2118/950091-G
4. Shchelkachev V.N. Vliianie radiusa i gidrodinamicheskogo nesovershenstva skvazhiny na ee proizvoditel'nost' [Influence of the radius and hydrodynamic imperfection of the well on its productivity]. Azerbaidzhanskoe neftianoe khoziaistvo, 1950, no.9, pp.5-10.

5. Horner D.R. Pressure build - up in wells. Proc. Third World Petroleum Congress. The Hague, 1951.

6. Glagovskii M.M. Debit skvazhin nesovershennykh po stepeni vskrytiia plasta [The production rate of imperfect wells by the degree of formation opening]. Trudy Moskovskogo neftianogo instituta. Moscow, Gostoptekhizdat, 1951, iss.11. 
7. Khein A.L. Teoreticheskie osnovy i metodika opredeleniia parametrov plasta po dannym ispytaniia nesovershennykh skvazhin pri neustanovivshemsia rezhime fil'tratsii zhidkosti i gaza [Theoretical foundations and methods of reservoir parameters determination from imperfect well testing data under unsteady liquid and gas filtration regime]. Voprosy razrabotki $i$ ekspluatatsii gazovykh mestorozhdenii. Moscow, Leningrad, 1953, pp.80-144.

8. Pilatovskii V.P. Vliianie prizaboinoi makroneodnorodnosti plasta na debit skvazhin [Influence of bottomhole macroinhomogeneity of the formation on the well rate]. Doklady Akademii nauk SSSR, 1953, vol.93, no.3, pp.417-420.

9. Issledovanie prizaboinoi zony plastov pri intensifikatsii dobychi nefti za rubezhom [Exploration of the bottomhole formation zone with intensification of oil production abroad]. VNIIONG, seriia "Neftepromyslovoe delo". Moscow, 1985.

10. Ponomareva I.N., Savchik M.B., Erofeev A.A. Usloviia primeneniia skin-faktora dlia otsenki sostoianiia priskvazhinnykh zon produktivnykh plastov [Conditions of skin factor use when estimating the state of the critical area of formation]. Neftianoe khoziaistvo, 2011, no.7, pp.114-115.

11. Savchik M.B., Ponomareva I.N. Assessment borehole cavity conditions while processing unrepaired pressure transient technique. Bulletin of Perm National Research Polytechnic University. Geology. Oil \& Gas Engineering \& Mining, 2011, no.2, pp.77-82.

12. Thomas G.B. Analysis of pressure buildup data. Petroleum Transactions of AIME, 1953, vol. 198, pp.126-128.

13. Pilatovskii V.P. Fil'tratsiia zhidkosti V nesovershennom plaste [Filtration of liquid in imperfect formation]. Osnovy tochnykh nauk, 1954, no.4, pp.121-132.

14. Shchelkachev V.N., Nazarov S.N. Uchet vliianiia gidrodinamicheskogo nesovershenstva skvazhin $\mathrm{V}$ usloviiakh uprugogo rezhima [Consideration of the influence of hydrodynamic imperfection of wells under conditions of elastic regime]. Neftianoe khoziaistvo, 1954, no.5, pp.35-41.

15. Vremennaia instruktsiia po ustanovleniiu tekhnologicheskogo rezhima i issledovaniia skvazhin [Temporary instruction for setting the technological regime and investigating wells]. Gostoptekhizdat, 1954, 55 p.

16. Vasil'evskii V.N., Kamenetskii-Fedorov S.G. et al. Vremennaia instruktsiia po gidrodinamicheskim issledovaniiam plastov i skvazhin [Temporary instruction for hydrodynamic studies of reservoirs and wells]. Moscow, Minnefteprom, Vsesoiuznyi nauchnyi issledovatel'skii institut, 1963, $68 \mathrm{p}$.

17. Stepanov V.P., Kuzmin V.M. Rukovodstvo po gidrodinamicheskim issledovaniiam neodnorodnykh plastov [Guide to hydrodynamic studies of heterogeneous beds]. Moscow, ONTI VNII, 1972, 159 p.

18. Mineev B.P. Opredelenie parametrov plasta po krivoi vosstanovleniia davleniia $\mathrm{s}$ uchetom gidrodinamicheskogo nesovershenstva skvazhin [Determination of reservoir parameters from the pressure recovery curve taking into account hydrodynamic imperfection of wells]. RNTS. VNIIOENG, seriia "Promyslovoe delo", 1976, no.6, pp.12-16.

19. RD 39-3-593-81. Instruktsiia po gidrodinamicheskim metodam issledovaniia plastov i skvazhin [Instruction on the hydrodynamic methods of formation and well studies]. MNP VNII, 1982, $180 \mathrm{p}$.

20. Mordvinov V.A., Ponomareva I.N., Voitenko M.A. Razrabotka usovershenstvovannoi tekhnologii provedeniia i obrabotki dannykh gidrodinamicheskikh issledovanii s tsel'iu uvelicheniia produktivnosti i optimizatsii rezhimov periodicheski rabotaiushchikh skvazhin [Development of advanced technology for conducting and processing data from hydrodynamic studies in order to increase productivity and optimize the regimes of periodically operating wells]. Perm', 2004, 170 p.

21. Shchurov V.I. Vliianie perforatsii na pritok zhidkosti iz plasta $\mathrm{v}$ skvazhinu [Effect of perforations on the inflow of fluid from the formation into the well]. Trudy Soveshchaniia po razvitiiu nauchnoissledovatel'skikh rabot $v$ oblasti vtorichnykh metodov dobychi nefti. Izdatel'stvo Akademii nauk Azerbaidzhanskoi SSR, 1953, pp.144-149.

22. RD 39-0147009-509-85. Rabinovich N.R., Il'iasov E.P. et al. Metodika otsenki kachestva vskrytiia plastov i osvoeniia skvazhin [Technique for assessing the quality of formation opening and well development]. MNP, VNII KS i BR, 1985, $36 \mathrm{p}$.

23. RD 39-100-91. Kuzmin V.M., Svalov A.V., Vakhitov G.G., Vasil'evskii V.N., Mamuna V.M. et al. Metodicheskoe rukovodstvo po gidrodinamicheskim, promyslovo-geofizicheskim i fiziko-khimicheskim metodam kontrolia razrabotki neftianykh mestorozhdenii [Methodical guidance on hydrodynamic, field-geophysical and physicochemical methods of control over the development of oil fields]. MINNEFTEGAZPROM, 1991, 540 p.

24. RD 153-3 9.0-109-01. Shagiev R.G., Kul'pin L.G., Levchenko V.S., Vol'pin S.G., Miasnikov Iu.A. et al. Metodicheskie ukazaniia po kompleksirovaniiu i etapnosti vypolneniia geofizicheskikh, gidrodinamicheskikh i geokhimicheskikh issledovanii neftianykh neftegazovykh mestorozhdenii [Methodical instructions on the complexation and phasing of geophysical, hydrodynamic and geochemical exploration of oil and gas fields]. MINENERGO, Ekspertneftegaz, 2002, 75 p.

25. Mufazalov R.Sh. Skin-faktor i ego znachenie dlia otsenki sostoianiia okoloskvazhinnogo prostranstva 
produktivnogo plasta [Skin factor and its importance for the evaluation of the condition of the near wellbore space of a productive formation]. Ufa, Izdatel'stvo Ufimskogo gosudarstvennogo neftianogo tekhnicheskogo universiteta, 2005,44 p.

26. Trushkin V.V. Metodika opredeleniia skin-faktora, razrabotannaia pri osvoenii Igol'sko-Tulovskogo mestorozhdeniia nefti [Method for determining the skin factor, developed during the development of the IgolskoTulovskoye oil field]. Georesursy, 2015, 1 (60), pp.7-12. DOI: $10.18599 /$ grs.60.1.2

27. Gidrodinamicheskoe sovershenstvo skvazhin [Hydrodynamic perfection of wells]. VNIIONG, seriia "Neftepromyslovoe delo". Moscow, 1983, iss. 1 (50).
28. Ibragimov L.Kh., Mishchenko I.T., Cheloian D.K. Intensifikatsiia dobychi nefti [Intensification of oil production]. Moscow, Nauka, 2000, 414 p.

29. Kaptsanov B.S., Fogel'son V.B. Obrabotka krivykh vosstanovleniia davleniia $\mathrm{V}$ neodnorodnykh plastakh [Treatment of pressure recovery curves in heterogeneous reservoirs]. Neftianoe khoziaistvo, 1984, no.2, pp.39-43.

30. Erofeev A.A., Ponomareva I.N., Turbakov M.S. Otsenka uslovii primeneniia metodov obrabotki krivykh vosstanovleniia davleniia skvazhin $\mathrm{V}$ karbonatnykh kollektorakh [Evaluation of conditions for the application of methods for processing well pressure recovery curves in carbonate reservoirs]. Inzhener-neftianik, 2011, no.3, pp.12-15.

\section{Библиографический список}

1. Van Everdingen A.F., Hurst W. The application of the laplace transformation to flow problems in reservoirs // Journal of Petroleum Technology. - 1949. - Vol. 1, № 12. - P. 305-323. DOI: 10.2118/949305-G

2 Joers C.J., Smith R.V. Determination of effective formation permeabilities and operation efficiencies // The Petroleum Engineer. - 1954. - № 11. - C. 15-22.

3. Miller C.C., Dyis A.B., Hutchinson C.A. The estimation of permeability and reservoir pressure from bottom - hole pressure build - up characteristics // Journal of Petroleum Technology. - 1950. - Vol. 2, № 4. - P. 91104. DOI:10.2118/950091-G

4. Щелкачев В.Н. Влияние радиуса и гидродинамического несовершенства скважины на et производительность // Азербайджанское нефтяное хозяйство. - 1950. - № 9. - С. 5-10.

5. Horner D.R. Pressure build - up in wells // Proc. Third World Petroleum Congress. - The Hague, 1951.

6. Глаговский М.М. Дебит скважин, не совершенных по степени вскрытия пласта // Тр. Моск. нефт. ин-та. М.: Гостоптехиздат, 1951. - Вып. 11. - С. 45-48.

7. Хейн А.Л. Теоретические основы и методика определения параметров пласта по данным испытания несовершенных скважин при неустановившемся режиме фильтрации жидкости и газа // Вопросы разработки и эксплуатации газовых месторождений. М.-Л., 1953. - С. 80-144.

8. Пилатовский В.П. Влияние призабойной макронеоднородности пласта на дебит скважин // Докл. АН СССР. - 1953. - Т. 93, № 3. - С. 417-420.

9. Исследование призабойной зоны пластов при интенсификации добычи нефти за рубежом // ВНИИОНГ. Серия: Нефтепромысловое дело. M., 1985

10. Пономарева И.Н., Савчик М.Б., Ерофеев А.А. Условия применения скин-фактора для оценки состояния прискважинных зон продуктивных пластов // Нефтяное хозяйство. - 2011. - № 7. - С. 114-115.

11. Савчик М.Б., Пономарева И.Н. Оценка состояния прискважинных зон при обработке недовосстановленных кривых восстановления давления // Вестник Пермского национального исследовательского политехнического университета. Геология. Нефтегазовое и горное дело. 2011. - № 2 - C. 77-82.

12. Thomas G.B. Analysis of pressure buildup data // Petroleum Transactions of AIME. - 1953. - Vol. 198. P. 126-128.

13. Пилатовский В.П. Фильтрация жидкости в несовершенном пласте // Основы точных наук. - 1954. № 4. - C. 121-132.

14. Щелкачев В.Н., Назаров С.Н. Учет влияния гидродинамического несовершенства скважин в условиях упругого режима // Нефтяное хозяйство. 1954. - № 5. - C. 35-41.

15. Временная инструкция по установлению технологического режима и исследования скважин. М.: Гостоптехиздат, 1954. - 55 с.

16. Временная инструкция по гидродинамическим исследованиям пластов и скважин / В.Н. Васильевский, С.Г. Каменецкий-Федоров [и др.]. - М.: Миннефтепром; Всесоюз. науч. исслед. ин-т, 1963. -68 с.

17. Степанов В.П., Кузмин В.М. Руководство по гидродинамическим исследованиям неоднородных пластов. - М.: ОНТИ ВНИИ, 1972. - 159 с.

18. Минеев Б.П. Определение параметров пласта по кривой восстановления давления с учетом гидродинамического несовершенства скважин // РНТС. ВНИИОЭНГ. Серия: Промысловое дело. 1976. - № 6. - С. 12-16.

19. РД 39-3-593-81. Инструкция по гидродинамическим методам исследования пластов и скважин. - М.: МНП ВНИИ, 1982. - 180 с. 
20. Разработка усовершенствованной технологии проведения и обработки данных гидродинамических исследований с целью увеличения продуктивности и оптимизации режимов периодически работающих скважин / сост. В.А. Мордвинов, И.Н. Пономарева, М.А. Войтенко; Перм. гос. техн. ун-т. - Пермь, 2004. $-170 \mathrm{c}$.

21. Щуров В.И. Влияние перфораций на приток жидкости из пласта в скважину // Тр. совещания по развитию научно-исследовательских работ в области вторичных методов добычи нефти. - Баку: Изд-во АН Азербайджанской ССР, 1953. - С. 144-149.

22. РД 39-0147009-509-85. Методика оценки качества вскрытия пластов и освоения скважин / Н.Р. Рабинович, Е.П. Ильясов [и др.]. - М.: МНП, ВНИИ КС и БР, 1985. - 36 с.

23. РД 39-100-91. Методическое руководство по гидродинамическим, промыслово-геофизическим и физико-химическим методам контроля разработки нефтяных месторождений / В.М. Кузмин, А.В. Свалов, Г.Г. Вахитов, В.Н. Васильевский, В.М. Мамуна [и др.]. М.: Миннефтегазпром, 1991. - 540 с.

24. РД 153-3 9.0-109-01. Методические указания по комплексированию и этапности выполнения геофизических, гидродинамических и геохимических исследований нефтяных месторождений / Р.Г. Шагиев, Л.Г. Кульпин, В.С. Левченко, С.Г. Вольпин, Ю.А. Мясников [и др.] / МИНЭНЕРГО, ФГУ «Экспертнефтегаз». - М., 2002. - 75 с.

25. Муфазалов Р.Ш. Скин-фактор и его значение для оценки состояния околоскважинного пространства продуктивного пласта. - Уфа: Изд-во Уфим. гос. нефт. техн. ун-та, 2005. -44 с.

26. Трушкин В.В. Методика определения скинфактора, разработанная при освоении ИгольскоТуловского месторождения нефти // Георесурсы. 2015. - 1 (60). - C. 7-12. DOI: 10.18599/grs.60.1.2

27. Гидродинамическое совершенство скважин / ВНИИОНГ. Серия: Нефтепромысловое дело. - М., 1983. - Вып. 1 (50).

28. Ибрагимов Л.Х., Мищенко И.Т., Челоян Д.К. Интенсификация добычи нефти. - М.: Наука, 2000. - 414 с.

29. Капцанов Б.С., Фогельсон В.Б. Обработка кривых восстановления давления в неоднородных пластах // Нефтяное хозяйство. - 1984. - № 2. - С. 39-43.

30. Ерофеев А.А., Пономарева И.Н., Турбаков М.С. Оценка условий применения методов обработки кривых восстановления давления скважин в карбонатных коллекторах // Инженер-нефтяник. - 2011. № 3. - C. 12-15.

Please cite this article in English as:

Dziubenko A.I., Nikonov A.N., Merson M.E. Increase in efficiency of methods of bottomhole formation zone treatment in active wells by information technique. Perm Journal of Petroleum and Mining Engineering, 2017, vol.16, no.2, pp.148-157. DOI: $10.15593 / 2224-9923 / 2017.2 .5$

Просьба ссылаться на эту статью в русскоязычных источниках следующим образом:

Дзюбенко А.И., Никонов А.Н., Мерсон М.Е. Информационный способ повышения эффективности методов воздействия на призабойную зону пласта в действующих скважинах // Вестник Пермского национального исследовательского политехнического университета. Геология. Нефтегазовое и горное дело. - 2017. - Т.16, №2. - C.148-157. DOI: 10.15593/2224-9923/2017.2.5 